\title{
DES MOINES M. E. CONFERENCE GROWTH
}

\author{
By The Rev. R. E. HaRVEY \\ II.
}

The End of the Beginnings

When the Iowa Conference met in Mount Pleasant on September 24th, 1856, in its thirteenth annual session, the brethren had much for which they could "Thank God and take courage." Although reduced in area to the four southern tiers of counties, the statistics showed that the churches in that territory had experienced an increase of almost two thousand full and preparatory members during the preceding twelve months, totalling a lay membership of 18,747. Church buildings had gained one-third in the same period, from seventy-eight to 104. Parsonages advanced from thirty to forty-three. There were fifteen fewer Sunday schools, but attendance on these showed one-third increase, being over 15,000 in all. Sunday school collections were seventy percent above the former year; contributions for the general Sunday school work of the church were doubled; missionary offerings of $\$ 2,389.13$ more than the refund of $\$ 2,150.00$ granted by the Mission Board for use in their own borders, and claims for pastoral support were paid up ninety-five cents on the dollar. The Annual Conference membership of 101, received twenty-nine accessions to their ranks.

Such general growth and prosperity fully justified the increase of their eighty-two parishes to one hundred and one, most of which were in the western part of the Conference, for the proper supervision of which a new District was created called Chariton. It was made up partly of charges detached from three older districts, partly of new circuits within its own bounds, and all lying west of the line which ultimately was fixed in once more dividing Iowa Conference. In fact, reading between the lines of conference legislation on various subjects, and the ar- 
rangement of circuits and districts, one can discern that the tide of opinion that had produced Upper Iowa Conference was still in flood, only awaiting the next General Conference to once more seek subdivision.

Of the nineteen new charges formed at this session in 1856, three were in Fort Des Moines District, the most important being Des Moines City Mission, E. M. H. Fleming, pastor. It has been noted that this worthy man, transferred from Indiana to Iowa Conference, was stationed at Monroe in 1855, a circuit extending far enough to the northwest that it brought him in touch with East Des Moines, then just finding a place on the map. The strategic value of its contiguity to the State capitol was so appealing to $\mathrm{Mr}$. Fleming that on the morning of November 4, 1855 he preached in the Harrison Lyon school house, located at what is now the southwest corner of Grand Avenue and East Ninth street, and on the first Saturday in December, began a protracted meeting in the same house, that resulted in the formation of an M. E. Class, which by the time Conference assembled, had grown to nineteen members and was detached from Monroe Circuit, with its founding father as first pastor. He remained two years in this vineyard of his own planting, erected and dedicated the first church building in East Des Moines, in which on February 28, 1857, the first east side Sunday school was organized, with Judge M. D. McHenry as superintendent. When the founder moved on to other scenes of action, the Mission had fifty members on its roll and has remained to this day a vital force in city life. Such were the beginnings of Des Moines Wesley Methodist Church. ${ }^{1}$

\section{City Mission Not Promising}

As matters then were, Rising Sun Circuit, in easterm Polk county, and Greencastle Circuit in northwestern Jasper, must have seemed vastly more promising than the city mission above described, respectively having 285

\footnotetext{
${ }^{1}$ Historical Sketch of Wesley Methodist Episcopal Church, a printed article evidently from a Church Directory issued in 1929 , and preserved among the Armstrong papers.
} 
and 155 members. The former was made up of outlying points on Fort Des Moines Circuit, and the latter of detached classes of Newton Circuit. Until these rural centers were replaced by upspringing stations along the incoming railway lines, they served their day and generation well, and were served by a line of faithful pastors. The first on Greencastle Circuit was Wm. Clarridge, who took under his care a society formed by the Rev. Caleb Bundy, at the home of John Butters, in what must have been a sort of no-man's land between Monroe and Rising Sun charges, and out of which in time developed the fine Prairie City Church. ${ }^{2}$

Offsetting these new circuits Adel and Panora charges were united for this one year with two ministers. John Anderson continued a second year on his Panora work, with Richard M. Donahoo as junior pastor, newly admitted on trial, but never advanced to full membership. He was consumed by a zeal, without proper knowledge of his own limitations, and intent upon obeying the mandate to "Never disappoint a congregation," he would travel his rounds all day with boots filled with ice water, collected in frequent immersions in the flooded streams and ponds that lay across his path, sowing the seeds of disease that cut short a promising career. Doubtless it was the martyr spirit; but, were such martyrdoms really necessary? Numbers of such instances may be found in early Methodist annals. ${ }^{3}$

The new Chariton District, with P. P. Ingalls as presiding elder, was almost one-half composed of new circuits. Some of them were results of dividing older, overgrown parishes, as in case of Chariton itself, which became a station, ${ }^{4}$ and Chariton Circuit took over the nu-

\footnotetext{
${ }^{2}$ History of Jasper County, by Western Historical Co., of Des Moines, pub. 1878 , p. 474 .

sAccount of the Rev. R. M. Donahoo is partly from local tradition in territory then included in Adel and Panora Circuit, partly from the narration of his wife, who after his decease married a well to do farmer of the writer's youthful acquaintance, and was related as an admonition to the "boy preacher" just entering the ministry against the earnest advice of two physicians.

" "Station," a pastoral charge consisting of a single church, in distinction from a "Circuit" which could have as many as the preacher could reach in a four weeks round, preaching every week day and three or four times on Sunday.
} 
merous rural churches scattered over Lucas county, although some of these may have been attached to Newbern Circuit, in southeastern Marion county. The name Decatur Mission appeared again on the Conference roll, being a circuit taken from Leon and LaGrange charges, having Decatur City as its head. But Mount Ayr Mission was virtually a new field, being the Ringgold county portion of W. C. Williams Afton Mission of the preceding year. The Rev. Jesse Sherwood, previously mentioned as first pastor of Hartford Circuit, came to Mount Ayr as its first resident minister, finding there a small society, the only one in the county. In November, 1856 he organized a second Class, which grew into a Church, that not only has functioned ever since, but has made an impress upon world wide Christian life, excelled by no other rural church of which this history treats, and equalled by few of more prominent standing.

This took place at the cabin home of Adam Talley, in the north part of Grant township. Mr. Tally was born in Delaware, where his forbears settled in 1686, and migrated westward in 1842, spending some years in Ohio and Indiana, in the last of which he traded his holdings for 120 acres of raw Iowa prairie land about two miles southwest of the present town of Diagonal on which he located July 4, 1856. It is probable that both the Reverends Wishard and Williams may have preached at this home, for Mrs. Talley had promised her Indiana pastor, that failing to find a church in her new location, she would herself found one; the Class formed by Mr. Sherwood numbered fifteen persons, members of three closely related families, the Talley's, Stahl's and Keller's, and the home was the place of holding services until sometime in the late 1860's a modest chapel named Bethel, framed of native lumber, was erected on the Adam Talley homestead. It was the first church building in the county, and gave name for a time to a rural circuit, until the establishment of a Star Route post office in the neighborhood called Goshen, caused the change of the circuit title. A railway station located close to Goshen post office, 
caused Bethel Class to move its location, and build a new church, old Bethel remaining as a mortuary chapel for the cemetery around it, where "Each in his narrow cell forever laid" sleep the fore-fathers and mothers of this church and community, many of whose descendants may still be found in the vicinity, while others are scattered from coast to coast, and some have carried the faith of the fathers clear round the world; all cherishing just pride in their descent from such worthy progenitors. When the Great Western railroad established the town of Diagonal, Goshen village moved bodily to the new site, the Methodist Church going along, both building and members. In due time the present attractive sanctuary was erected, and upon a memorial window are blazoned the names of the "Talley's Class" of 1856.5

That this was not the only Class formed that year or soon after is fairly certain. Mount Ayr Mission reported 175 members in 1857, and a few years later the printed lists of missionary contributors in the Conference Minutes made mention of Ruby's, Millsap's, (two of them) Week's, Lesan's, Marshalltown, Eugene, Caledonia, the distribution of these place names indicating a very complete preemption of the entire county by the people called Methodists. Jesse Sherwood gave two years service to the charge, succeeded by Calvin Spooner for a like term, and in 1860 was Mount Ayr "Mission" no longer, but "Circuit," with 192 full members and 130 probationers, the second strongest parish in the District to which it belonged.

\section{ADAIR COUNTY AT LAST ENTERED}

Adair county, the last in the third tier from the south to be entered by Methodist preachers, was pioneered by the Rev. Charles G. Milne, while a local preacher, who, as best we can determine from conflicting statements of dates, delivered the first sermon in the county in 1855,

\footnotetext{
5The account of Adam Talley and the Talley Class is from a paper read by Miss Eva Stahl, grand-daughter of Mr. and Mrs. Adam Talley, at the golden anniversary of the Diagonal Church. Much of the remainder comes from personal recollections, for old Bethel was my church and Sunday school home for some years, and I was guest in the homes of some of the founding fathers and mothers.
} 
at the home of R. M. Ewing of Richland township, in the southwest part of Adair. Placed on the Conference roll in 1856, "To be Supplied," it may well be that Mr. Milne labored here until 1857, when he was admitted on trial to Iowa Conference and stationed in the eastern portion of the state. No statistics for Adair Mission were handed in at the 1857 session, so no idea can be had as to results achieved. William Clarridge was pastor in 1857-58, and the only report was of seventeen members, quite easily explaining why Adair was omitted from the appointments for the ensuing year; also, according to local historians, why the Revs. J. M. Rust, from Lewis, and Wm. Howbert from Quincy, both held services in Greenfield and probably elsewhere that year. Mr. Howbert formed a Class of ten in Greenfield in the summer of 1859, which society was served, in conjunction with the pastors, for several years by the Rev. Samuel Osborne, a local preacher of whom we have no further record. The first Class in Adair county however was formed in 1857 in Jefferson township, consisting of two men and their wives, but by whom assembled or to what charge attached, historians have not informed us if they knew themselves.

This brings us down to the Conference of 1859, when the Rev. J. W. Todd, another great name of Des Moines Conference, was appointed to Adair Mission and laid out a circuit including Greenfield, Fontanelle, Root's, Wahtewah, Salem, Nevinville, in Adams county, and Middle river in Madison. The Rev. I. I. Stewart, presiding elder of Council Bluffs District, held the first Quarterly Meeting in Greenfield Dec. 17, 1859, the pastor and four official members being present. The statistics for 1860 gave Adair 41 full and preparatory members, and $\$ 6.00$ contributed for missions. The pastor received $\$ 123.00$ out of $\$ 175.00$ promised him. $^{\circ}$

There was great expansion elsewhere in Council Bluffs

"Adair County, from History of Iowa by Counties, Publishing Co., of Springfield, Ill., from article on history of $M$. E. Church in that county by the Rev. J. A. Wilson, who received a great deal of. his information from a long letter by the Rev. J. S. Lisle, who was pastor of Adair Mission 1862-63 ; Also some items from Adair County and Its People, by Pioneer Pub. Co., of Chicago, 1916. 
District. Although Afton Mission had gone to Chariton District, and Panora was restored to Fort Des Moines District, they were amply replaced by the 1856 Conference. Pottawattamie Circuit reduced the area of Council Bluffs Mission by removing the eastern part of the county so named, although this may have been only a new name for the "Nishony" charge mentioned heretofore. Work had begun at a very early date in this field, though by whom there is no certain record; but the Rev. Moses F. Shinn, first presiding elder of Council Bluffs District, held a Quarterly Meeting at or near Avoca in 1853. The name "Pottawattamie" appeared only once more, in 1857 , when it was bracketed with Lewis. Somewhere in that area New Town, a long since vanished population center, built a parsonage for the Rev. John Wilson, supply pastor, but just when, the county historians have not made clear, for with some of them, the fixing of dates and localities was far from an exact science. ${ }^{7}$

The foregoing applies to Fayette Circuit, to which Richard Mulholland was appointed in 1856. First named on the Conference roll this year, it appeared no more, although in 1857 reporting 240 members, with church and parsonage valued at $\$ 800.00$ each. Until informed as to what limbo of lost townsites received Fayette, nothing more can be told of its origin or fate.

Comes now a different story: Page county, cutting loose from its old running mate, adopts a new name, acquires a new partner and blooms out as "Clarinda and Montgomery Mission," and not unmindful of its past, takes Samuel Farlow as pastor, and William Howbert as co-worker. Of the Clarinda portion it is only necessary to say that it boasted a parsonage. Of Montgomery there is much to report, both from authentic records and personal knowledge. It was the last county in the second tier to be organized as a political unit, owing to the diversion of emigrant travel to either the "State road," running from county seat to county seat through the first

${ }^{7}$ History of Pottawattamie County; "Early and Present Religious Organizations," by Historical Department of Iowa, pub. 1883. 
tier north of the Missouri line, or to the "Mormon Trail" traversing the third tier; leaving this remarkably fine expanse of land unseen, and therefore unknown to the mass of homeseekers, with the consequence that only eighteen votes were cast in the organizing election in 1853.

The first sermon in the county was delivered by the Rev. Mr. Rand, of Adams county, at the first Montgomery wedding, in the home of Reid Donahoo, on the east side of the West Nodaway, near Milford (Grant). The contracting parties were Samuel McNeeley and Martha Donahoo, and their union had the full sanction of both Church and State, since the County Judge, who issued the license and made the record, was present and participated in the ceremony. The sermon seems to have been thrown in for good measure, the guests being anxious to benefit as largely as possible from this first ministerial visit to their community.

\section{UNIQUe Personality ENTERs Field}

Somewhere about that time there moved into the Milford neighborhood a local preacher named William $\mathrm{T}$. Reid, familiarly called "Uncle Billie," a man of the frontier and such as only frontier conditions could have produced. Converted in his native Virginia "with a real experience of Jesus Christ," his westward trek took him to Illinois, where for several years this writer's grand-father, a Methodist Class Leader for forty years, was Uncle Billie's song leader in revival meetings over a wide expanse of country. When Illinois became over-crowded for his taste, Mr. Reid moved to a newer frontier, and true to his call, in 1855 or 1856, organized a Methodist Class at Milford, in which Samuel McNeeley and wife, the Reid and Allen Donahoo families, William Stipe, wife and son David, and the Wm. T. Reid family were charter members.

When the office of county superintendent of schools was created, Uncle Billie was chosen, despite a very sketchy education, picked up by the wayside of his migra- 
tions, causing a sarcastic Illinois acquaintance to remark: "He had better have gone to school awhile himself before telling other folks how to teach." As evangelistic helper and supply pastor, Wm. T. Reid travelled many neglected fields, won many souls to Christ, and organized a number of churches, the most prominent being that at Villisca, formed in 1866. The nick-name "Funny Preacher" conferred on him in Greenfield, was a very fair characterization of the whimsical old man, who, so poor in this world's goods that he left barely enough to afford him respectable burial, yet made many rich both for time and eternity.

Returning to 1856, Samuel Farlow preached the first sermon in Red Oak, to a congregation of six, in the home of L. M. Hocking, on what is now East Coolbaugh street. Frankfort, six miles east of Red Oak, laid out as the county seat, (now marked only by a school house and cemetery) was made an appointment about as soon as it took form and place, and the work made such apparent progress that in 1857, "Montgomery Mission" stood alone, with Richard M. Donahue, pastor, who traveled these rolling prairies with the same ardor as drove him through Dallas and Boone marshes and ponds. But hard times were upon the land, the preacher was paid only $\$ 160.00$ of the $\$ 450.00$ pledged, and, probably for this reason, Montgomery did not appear in the 1858 appointments, being most likely re-attached to Clarinda Circuit, but in 1859 , it was once more on the roll, marked "To be Supplied," the Supply in this instance being "the circuit rider without a horse," the Rev. Jeremiah T. Hughes.

Almost half a century after the event, in a Conference Love Feast "Uncle Jerry" related with gusto, how on his foot pilgrimage from Muscatine, seat of the 1859 Conference, he was overtaken by night on the prairie, made his camp near the church in which he was talking now stands, read his bible by firelight, and held "the first religious service in Creston," in which his prayers and "hymns of lofty praise" awakened the echoes - and 
wolves-who reciprocated his vocal melodies by lulling him to sleep with their responses.

Arriving at the home of "Uncle Billie Reid" almost barefooted, the preacher promised a Milford store keeper to pay for a much needed pair of boots out of his first quarterly missionary stipend of $\$ 10.00$, due from New York in three months. Now, New York was a long way off, the Mission Board an unknown institution to that merchant, so the boots remained on his shelves. Tramping on to Frankfort, Mr. Hughes retold his needs and pledge of payment to another merchant who, confessing himself very much less than an exemplary character, for the sake of his Methodist mother, who was still praying for him in Kentucky, gave the desired credit. Hearing of the affair, Mr. John H. Murray, who then and thirty years subsequently, kept "Preacher's Hotel" at Frankfort, staged a canvass among the county officers, and presented the preacher with his store account receipted in full; a direct answer to prayer, as the beneficiary declared then and always believed.

Less fruitful of immediate results was a prayer offered by Mr. Hughes in Red Oak, where the Hocking home as a place of meetings had given way to a building often devoted to other gatherings, as the preacher found on one occasion, when the room was engaged for a dance the same evening; pleading in vain that his regular announcement for services constituted a prior claim, Mr. Hughes accepted a proffered compromise, whereby he was permitted to offer prayer, and then withdraw; that Uncle Jerry put a lot of energy-and time-into that petition to the throne of grace, we who knew him can well believe; that done, the merry makers proceeded to warm up their cold feet with fourfold zest. ${ }^{8}$

8Principal source of authority for Montgomery county, History of Montgomery County, Chap. XXVIII, "Religious Organizations in the County", by W. W. Marritt, a Universalist clergyman-farmer, pioneer resident of the county, and personally acquainted with most of the persons and events commemorated by him. Also. Higtory of Montgomery County, by Iowa Historical and Biographical Society, pub. 1881. The writer of this article spent two and a half years in Montgomery county, and John H. Murray's house was his second home, as it had been to many Methodist preachers before him. An appraisal of "Uncle Billie Reid", is among the Armstrong papers. 
Statistical records of 1860 showed Montgomery Mission contained eighty-four members, and two Sunday schools with attendance of ninety-four. In money matters the presiding elder's claim of $\$ 56.00$ was met in full. Whether the pastor, who was allowed $\$ 156.00$ salary and moving expenses, received anything besides his $\$ 40.00$ missionary money, did not get into the report. But Conference admitted Jeremiah T. Hughes on trial, and appointed him junior preacher on Mount Ayr Circuit, so we can be sure he felt his labors had not been in vain.

\section{Shelby AND Audubon EnTEREd}

Council Bluffs District included one more new field in 1856 ; Audubon and Shelby Mission, J. M. Baker, pastor. There had been a "Shelby Mission" in the 1855 "Supply" appointments, which reported twelve members in 1856. We have previously noted the introduction of Methodism into Shelby county, in 1854 by Rev. and Judge Harting A. Tarkington, who may have been the supply for 1855 . Audubon county was entered from Cass, Exira being an appointment of Cass Mission in 1855, a Quarterly Meeting held there in September of that year, indicating that work had been in progress there for some time. Now as James S. Rand preached in Cass in 1854 and was continued in 1855 , we may safely assume, until other evidence corrects us, that he pioneered Audubon, as well as several other counties. The Mission served by J. M. Baker in 1856 reported next year fifty members and ten probationers; also one Sunday school, with fortyseven enrollment. In the 1857 appointments, Audubon stands alone, with J. M. Baker continued, but no mention is made of Shelby. In 1858 Audubon reported seventythree members and probationers, and was joined up with Lewis, J. M. Rust, pastor; while Shelby re-appears as "Harlan, To be Supplied"; from which charge the same number of members were returned in 1859 as in 1856. Nevertheless the name continued on the Conference roll, and as a supply charge, the supply in this and probably the preceding year, being the Rev. Kirtland Card, at 
whose home the Church first broke ground in Harrison county. He was an Ohioan, of Scottish descent, of manly calibre and Christian grace; later he gave a few years to the itinerant ministry, until superannuated by impaired health. His 1860 report gave Harlan Mission sixty-eight members, and credit of paying one-half of the $\$ 320.00$ allowed the pastor. ${ }^{9}$

Other developments in the Council Bluffs area may here be considered. Taylor Circuit, separated from Page in 1856, had Isaac Kelley for pastor who remained two years, during which period Classes were organized at Memory (New Market) and at Bedford, the latter of such proportions and promise as to give name to the parish in 1858, when the Rev. W. S. Peterson took charge of the circuit. He organized at Buchanan, (Siam) and doubtless other places, for in 1859 when James S. Rand came to Bedford Circuit he found 170 full members in the charge, to whom a year of sweeping revivals added 178 probationers; and also there were reported five Sunday schools, enrolling 275 attendants. ${ }^{10}$

1857 saw Buena Vista added to the Conference roll, due to division of Harris Grove Society, some members choosing to favor this new town, which flourished long enough to rank as head of a circuit for seven years. It was attached to Magnolia Circuit for one year, then vanished, the name meantime having been changed to Whitesboro, and the very site long since abandoned, as growing railway stations crowded it off the map. Elsewhere in Harrison county Woodbine M. E. Church was organized in 1857 by the Rev. James S. Rand; Little Sioux Class came into being in 1858 , and the same year a class was formed at St. John, on the south line of the

"History of Audubon County, Western Historical Society, pub. 1887. History of Shelby County. same firm. Also very ample resume of Harlan M. E. history, by the Rev. A. R. Miiler, at Fiftieth Anniversary, in 1909. Found in Armstrong papers.

${ }^{10}$ The M. E. Church in Taylor County, pp. 461-2, History of Taylor County, by Western Historical Society, of Des Moines, pub. 1881. The Methodist Church in Taylor County, in History of Taylor County. by State Historical Society, pub. 1881 ; also a History of Taylor County, pub. in 1910. 
county, to which Missouri Valley Methodist Church attributes its origin. ${ }^{11}$

Very similar to the legend of Buena Vista, with a more ambitious vision and still more abrupt demise, is the story of the rise and fall of Louden. Where was Louden? Some years back, around the turn of the century, when Hillsdale, in central Mills county, was still a railway station, visitors were shown some crumbling stones as sole relic of a monumental enterprise in education, which, could it have materialized, would have set Louden alongside Evanston, Greencastle, Durham and other Methodist seats of learning. For those stones were all that remained of "Columbus Seminary," for the erection of which a vast real estate speculation, expected to yield profits of $\$ 25,000.00$, was launched by the Rev. John Guylee, second presiding elder of Council Bluffs District, in conjunction with others likeminded, including some Nebraska residents, perhaps with the thought of uniting Iowa and Nebraska Methodism in support of one great institution, to be constructed and supported by proceeds of land sales.

Their proposal to erect a three-story stone college building, and their financial status seemed so assured that in 1857 Louden was detached from Glenwood Circuit, and made a station with membership, on paper at least, of over 200. The glowing reports of progress brought up to the Conference of 1858 caused the appointment as pastor of Louden Station and headship of the incipient seminary, of the scholarly Rev. Strange Brooks, who moving thither via covered wagon, found neither town, meeting house, nor school where he had been given reason to expect all three. Disgusted and disappointed Mr. Brooks drove on to Kansas, where plenty of Methodist preacher work awaited any good man. ${ }^{12}$

Rallying all their energies the sponsors set about the

${ }^{11}$ History of Harrison County, National Pub. Co., Chicago, pp. 130, 154, 219ff, Churches, Buildings and Parsonages, Sec. Methodists, from Chap. I'X History of Harrison County, by Joe H. Smith, 1888.

${ }^{12}$ History of lowa Conference, by the Rev. E. H. Waring, pp. 157-58. 
erection of the $\$ 25,000$ college building, and in 1859 secured the creation of Louden District, covering eight counties, reaching eastward to include both Afton and Mount Ayr, with Mr. Guylee as presiding elder and the devoted Richard Donahue as pastor at Louden, where in December 1859 he "ceased at once to labor and to live." The building was pushed on toward completion and had reached the third story when a terrific tornado levelled all with the ground, wrecking alike the project and the hopes of the promoters, who were left financially prostrated by the disaster. Louden District passed from the Conference rolls in 1861, Louden town had never fairly come into being, and all that is left of Columbus Seminary are some pages of reports and resolutions in Conference Journals eighty-five years old. ${ }^{13}$

\section{LINCOLN LOCATED BRIDGE}

May we glance at one more forgotten dream on this western edge of our domain before looking back east? Somewhere north of Pacific Junction, one familiar with the ground might point out "Pacific City," once boomed as the point where the Pacific railroad should cross the Missouri river, making it the eastern terminus of that highway of traffic. Here in 1859 a group of five Methodists obtained the status of "Supply Charge" in Iowa Conference. If anyone supplied Pacific City that one year of its existence he is unknown. A consultation held that very year on Prospect Point, Council Bluffs, by Chief Engineer Grenville M. Dodge and a tall, angular Illinoisan signing himself A. Lincoln, forever fixed that river crossing where it is, and laid to rest half a dozen schemes as hopeful as that at Pacific City. ${ }^{14}$ Pacific City Class long survived as a point on Glenwood or other circuits contiguous, although now I believe merged with the Pacific Junction Church.

While following Council Bluffs District triumphs and defeats to the end of the quadrennium, we have not for-

${ }^{11}$ History of Mills County, by State Historical Department of Iowa, 1881. 
gotten the older fields. Des Moines District registered one new charge in 1857, Wheeling Circuit, in northwestern Marion county, strategically located to close the gap between Monroe and Hartford Circuits. 1858 added two new names: Lawrenceburgh, in Warren county, the beginning of which we have no exact data. It paid its pastor that first year $\$ 275.00$ and could afford it with a membership of 372 , of whom 125 were new converts. The other, Beaver Circuit, lay along the stream of that name in western Polk and northeastern Dallas counties, taken out of Adel and Des Moines Circuits. This circuit paid its pastor $\$ 140.00$ for that year, exactly fifty cents per member, but it was all they promised, and they paid it in full.

All three of these circuits remained in Des Moines District in 1859 , but no others were added and several older charges were transferred to other districts. Another change occurred relating to the district title, for in 1857 the military praenomen "Fort" was erased; seemingly Capital City dignity no longer admitted such reminder of its recent frontier status. And farther approximation to metropolitan honors, in 1858 the church on the west side in Des Moines became a Station, known as Fifth street, all its country preaching places being assigned to adjacent circuits.

Chariton District showed no expansion in 1857, but 1858 added two new circuits, both carved out of older ones. The Rev. Jesse Sherwood, in 1856, held the first religious service at New Virginia, under a tree in John Felton's door yard, at the close of which a Class of nine was formed, progenitors of the Society that has kept up services in that community ever since, and which in only two years time became head of the circuit so named. The same year a Class of twelve at Norwalk inaugurated church work that has been just as permanent, but not arriving at separate pastoral charge status quite so soon, although it has been served by some of the most prominent of Des Moines Conference ministers. Smyrna Cir- 
cuit took place in Chariton District in 1858, appearing under that name only that one year, being apparently renamed "New York" in 1859, a title that graced the Conference rolls until a comparatively recent past.

1859 added three names in Chariton District. "Liberty and Ottawa" circuit in Warren county, originated in a revival at Liberty Center, conducted by the Rev. J. W. Todd, assisted ably by two laymen, John and George Covell; a Class of eighty was formed here in 1857, the leader of which, Joseph Michaels, lived to the unusual age of one hundred and two. He was vigorous enough to attend a Centenary service held in his honor, and listen to sermons both morning and afternoon, and at the close of the second discourse, delivered an address that thrilled his hearers intensely, none perhaps of whom had ever listened to a speaker one hundred years old, and to them his words sounded like a message from the spirit world. ${ }^{15}$

Garden Grove slipped from the leading strings of the county seat in 1859 , becoming the third pastoral charge in Decatur county, and has retained its independence ever since. And Hopeville, Clarke county likewise be: came head of a circuit extending into Union, Ringgold and Decatur.

\section{Division OF THE CONFERENCE}

Iowa Annual Conference transacted a lot more important business at its sixteenth session held in Muscatine, commencing September 7, 1859, Bishop Matthew Simpson presiding, besides forming one new district and a number of new parishes, but that which most concerns this chronicle was comprised in the report of the Committee on Division of the Conference :"

The Committee on Division of the Conference respectfully report: That a division of the Conference is necessary, and they recommend the following line for consideration and adoption.

Commencing at the Southeast corner of Wayne county, thence due north to the northeast corner of Lucas county, thence due east

10History of Warren County, by the Rev. W. C. Martin, 1908, for all Chariton District items pertaining to Warren County. Balance are from Conference Jour-
nals. 
to the corner of Marion and Mahaska, thence north till we strike the Des Moines river, thence up said river to the northern boundary.

All the territory west of said line to be called the Des Moines Conference, and all the territory east to comprise the Iowa conference.

Immediately a motion was made, and, after debate carried, striking out the second paragraph and substituting the following:

Commencing at the southeast corner of Wayne county, and running due north to the line of the Upper Iowa Conference, leaving Knoxville on the west, and Monroe, Newton and Greencastle on the east of said line.

Certainly a much more direct line than the other, and, whether by accident or design, paralleling within a mile or so, the old time barrier between civilization and savagery, the "Red Rock Line," which we saw in the beginning of this article as the extreme western limit of Methodist occupation when Iowa Conference was organized.

Following this amendment came another changing the title of the new administrative unit to "Southwestern Iowa" which also prevailed. So far, good; but in electing five delegates to the ensuing General Conference, to meet in May, 1860, by which body these proposals must needs be considered and validated, the entire quota was chosen from ministers stationed east of the boundary.

As the finale to their projected separation, the Conference fixed upon Oskaloosa and Indianola as meeting places for the two bodies in 1860, and asked Bishop Simpson to conclude the session by administering the Lord's Supper to the assembled ministers, very few of whom would ever look upon each other's faces again in this life. For reasons unstated this service appears to have been omitted, for the session closed with the usual address by the bishop, the reading of appointments for the ensuing year, and prayer, very appropriately, by the Rev. William Simpson, whose ample experience over the entire area made him completely representative of both the old and the new. 
We have now traced as accurately as available records permit, the rise and progress of the Methodist Episcopal Church in southwestern Iowa into strength sufficient for a self determining unit of its denomination. Before taking up the aftermath of the sixteen years of seed-sowing and cultivating productive of that end, it seems just to give some notice to the group of ministers to whom were committed the destinies of the new Conference; the preachers who, by assignment to the four western Districts of the Iowa Conference in 1859, became thereby charter members of Western Iowa Conference in 1860. As this appraisal of work and character is based largely upon their obituaries in Conference Journals, we present only those who by devoting their remaining years to the new Conference, have left such records in our reach. Their memorials are here given that their successors may know what manner of men they were in whose footsteps we follow.

\section{Charter Members}

The first memoir printed in the Minutes of Western Iowa Conference for 1860, was strictly speaking not of a Charter Member, since he passed away before that body had a being; but as his brief life work was all devoted to its area, and as no memorial of him would appear elsewhere we give it here, although already considerable space has been allotted to the same over-zealous soul:

Rev. R. M. Donahue, probationer in this Conference, sweetly fell asleep in Jesus, Dec. 21, 1859. He was born near Peoria, Illinois, Sept. 24, 1834; converted at the early age of seven, and joined the M. E. Church; was admitted on trial in the Iowa Conference, in the year 1856 and traveled the Adel Circuit, where, through excessive labors, he laid the foundation for an early decline in health. Subsequently he was appointed to Montgomery Circuit, next to Council Bluffs, and lastly to Louden, when almost at once he ceased to work and to live.

Charles Woolsey, first full member of Des Moines Conference in her necrology, entered the ministry in 1853 late in life, aged fifty-four. He spent three years in the eastern part of the state, then came to Glenwood, thence 
to Sidney, Clarinda and Brooklyn, serving each circuit two years, the time limit at that period, which fairly represents the acceptability of this amiable, scholarly, devout, but not brilliant man. He was still in the effective relation at his death when sixty-five years old; a rather unusual record in that short-lived era.

Sanford Haines entered the ministry in Ohio, came west in 1850, and was pastor of Fort Des Moines Circuit in 1851-52. After seven years in the leading pulpits of the older part of the Conference, he was appointed presiding elder of Des Moines District in 1859, and had much to do with proceedings whereby the Conference division of 1860 took place, also as delegate to General Conference in 1864 assisted in rectifying the boundaries as fixed in 1860. With impaired health when he left the district in 1863 , he took light circuit work contiguous to Des Moines until appointed to Indianola District in 1870, in which office he died in January of 1871. "As a preacher Brother Haines was thoroughly in earnest; he was cautious in his propositions, clear in his statements, terse, pungent, forcible in arguments, apt in illustrations, warm and impassioned in application, often rising to the higher realms of pulpit eloquence and power. He also was a faithful pastor. The tenderness of his soul was drawn out in the chambers of the sick, and his appropriate prayers remained like celestial visitants to comfort and bless the sick, long after the pastor departed."

Of John M. Rust, who died in March, 1871, little can be said as no memoir of him was ever published. Admitted on trial in 1855, his work after one year was successively Magnolia, Lewis and Audubon, Sidney, and Hawleyville; here he enlisted in the Fourth Iowa Cavalry, for Civil war service, starting as second lieutenant, and attaining captain's rank, then resigned after eighteen months. Local tradition says that he fell from grace during his army life, which explains why he was reported to the Conference in 1863 as "Suspended" and a year later referred to the presiding elder of his district for investi- 
gation; in 1865 he appeared before Conference, confessed his downfall, of which he professed himself deeply penitent, and was granted a location (i.e. discontinued as Conference member, but continued as an ordained local preacher). No more is known of him until in 1870, when he was readmitted to Conference membership, and appointed to Vermillion, Dakota Territory, where he passed away the following spring.

Enoch Wood also has no obituary or account of his earlier years. He began his ministry in Indiana, 1832; transferred to Iowa Conference in 1853, and stationed on Boone Mission when it "extended from Saylorville to Boone river." He served Lawrenceburgh two years, Hartford one year, and Ottawa two years, then was superannuated until his death in 1873.

John Wesley Todd, deceased June 21, 1879, truly a son of Des Moines Conference, was converted in Warren county, and admitted on trial at the first session held in Des Moines, 1857. Was appointed to Adel as junior to Allen W. Johnson, that splendid operator of new mission fields, and their joint efforts made possible the setting off of Beaver Circuit from Adel, with Mr. Todd as pastor. Next he brought Adair Mission onto the Conference map; went to the Missouri slope and served Louden, Council Bluffs, Glenwood; came back east, to Wesley Church, Des Moines; then to Osceola and Garden Grove; came next four years as presiding elder of Fort Dodge District, then in Des Moines Conference, covering twelve thinly peopled counties, in which he averaged two new circuits per annum, helping greatly toward the formation of North West Iowa Conference, from which he promptly transferred back home, and a year later was presiding elder of Chariton District, for four highly useful years; then went as pastor to Winterset, and nine months later, after brief illness "was not, for God took him." His two sons followed him into the ministry, and gave Des Moines Conference some useful years of service. The younger, Edward H., now enjoys the well-earned honors of emeritus president of Puget Sound University. 
David N. Smith, due to some physical ailment that permitted a successful business career, was unable to discharge regular ministerial service, his only pastorate being at Fifth street, Des Moines, in 1863, during which year he extricated the congregation from bankruptcy, completed the church building, and ushered in a regime of prosperity for Des Moines Methodism. Even when engaged in secular pursuits he preached whenever able, and gave great encouragement to young men seeking education, especially if headed toward the ministry. He served well as a college trustee, and dying had made provision for generous bequests to college endowment funds. His passing occurred July 25, 1879.

John M. Baker was an Ohioan, who moved to Bedford, Iowa, in 1855, and with his wife became charter members of the Methodist Church in that place. Admitted to Iowa Conference in 1856, he first served Audubon and Shelby Mission, when there were but fifty Methodist members in the two counties. During eleven years in the itineracy, he served Buena Vista, Corydon, Mount Ayr, Decatur City; but impaired health placed him on the superannuate roll, and after nineteen years of farm life, he "died in great peace" Dec. 22, 1886.

Michael Sheets, Virginia born and converted, entered the ministry in Ohio, where he attained great success as a revivalist, adding a hundred or more converts per year to the kingdom. Coming to Iowa in 1859 , he was appointed to Afton, placing him in the new Conference, to which he gave seventeen years of good service despite a feeble frame and halting utterance. Never taking high rank, he was faithful to his church, his parishioners, and his family; moving many to wonder how on such meager salaries as then paid he was able to give his three children comfortable nurture, complete college courses, and leave his widow a modest competance.

\section{SACRIFICES OF PREsIding Elders}

Arthur Badley came to Iowa in 1857, after fifteen years ministerial service in Indiana. $\mathrm{He}$ was pastor two 
years at Knoxville, then one year on Hartford Circuit, then in 1860 was appointed presiding elder of Council Bluffs District. He took up his residence at Lewis, so that upon the discontinuance of Louden District, and the remodelling of Council Bluffs District, he was continued on Lewis District, for the full four year term of hard labor and sacrifices unbelievable by men of later generations. From the district he went to Indianola, and when at the end of that year, Indianola became a station, he continued on the rural work, under name of Indianola Circuit; from thence on an itinerary of circuits, most of which he served the full pastoral term of three years, introduced in 1864. With failing health came superannuation in 1880, and the final end Nov. 30,1887 . He left, as his chief bequest to the Church and world, a son, Brenton H. Badley, who followed the gleam to far off India, and wrote his name large on the expanding map of Christ's kingdom, and where a son and grandson carry on the family tradition of ministerial service.

Of Uri P. Golliday the writer saw much and heard more, since as the budding youth, perhaps because of bookish inclinations, enjoyed attentions beyond his desserts from this favorite family pastor and frequent guest, and later the fledgling preacher profited by gifts of books, manuscripts, sound advice, wise counsel, and constructive criticism of his crude sermonic efforts. My first pastorate, spent where he had long made his home, afforded further opportunity of acquiring information concerning one, who to me was indeed a father in Israel.

He was born in Ohio, reared in the tenets of her faith by a devout Quaker mother, so, even after joining the M. E. Church, he was a probationer for some years, rather than accept the ordinances of baptism and the Lord's Supper. Giving himself, at the insistence of his Methodist wife, to the examination of these subjects, he studied the Quaker views as contained in controversial works in the library of a Quaker preacher uncle; dissatisfied with what he found, he sought other informants, 
and finally presented himself and his three children for holy baptism, and throughout life was an ardent champion of the two sacraments as of divine institution. Taking up medicine, he became a graduate M.D. in days when such were scarce; entered the ministry as a local preacher; was admitted on trial by Rock River Conference, and in 1859 transferred to Iowa; was stationed at Council Bluffs, and ranks as charter member of the Conference to which he gave twenty years of hard work, before superannuation at seventy. Twelve years pastor of leading churches, one year chaplain of the 34th Iowa Infantry, three years conference agent of the American Bible Society, four years presiding elder of Quincy-later Corning-District, besides active participation in all Conference business, his work on leading committees bulking large in the journals of those years. Such was his official record.

Precise and convincing in his preaching, he was said to have written out every sermon in full before delivery, seldom departing from this prepared text. As defender of the faith delivered to John Wesley, he joyfully met all comers in the controversial lists, proving an opponent worthy of any foeman's steel. Endowed with a rich sense of humor that could bite like an adder, he characterized an exceedingly neutral-tinted person as "represented algebraically by a cipher preceded by the decimal point." Or when a finicky young colleague, obsessed with the idea that frail health was indicative of holiness, asked a hard-worked hostess for an egg beaten very light sprinkled with sugar, the irate old man exclaimed, "And Sister Beall, kindly bring a pillow for the young brother to sit on, and another to support his head while he partakes of such rich food, for I fear he is in a very low state!" Wit like that implies an under stratum of volcanic temper, which the good man had, on rare occasions boiling over with staggering effect upon the object of wrath, except in case of his companion, equally highspirited and vocally gifted with himself. Long after both were gone, neighbors in old Quincy, where the Golliday's 
resided for some years, spoke admiringly of the "scientific quarrels" that sometimes made electric the atmosphere, all the more awesome that they were couched in classical terms but little understood by the poorly educated hearers. By a less serious foible, surprising in one of such logical and well-poised mind, he entertained a tolerant credulity, amounting almost to belief, for the vagaries of clairvoyance. A strong city church, and two thriving village congregations, all founded in his declining years, are monuments to his memory in the vicinity where he lingered out his last painful, afflicted sojourn. The "M.D." earned in youth was in old age reinforced by the clerical "D.D." both well won and worthily worn.

Jesse C. Sherwood was another who waited until past middle age before listening to the ministerial call, being admitted to Iowa Conference in 1853 when forty-nine years old. His active ministerial labors were confined to a single decade, followed by another in which supply work was interspersed with inactive periods, then came thirty-eight years of retirement. His best record consists of the resolutions of respect adopted by those who knew him best, the Quarterly Conference of Attica Charge, where he spent those last superannuated years; his death occurred Feb. 4, 1893, in his eighty-ninth year.

John M. Conrad was born in New York, reared in Indiana, where he left college at twenty years of age to enlist for service in the Mexican war. Coming to Iowa, he alternated between school teaching and farming, until at thirty he was converted at Decatur City, and soon after, via the exhorter and local preacher route, was ushered into the itinerant ministry and in 1858 stationed at Lawrenceburgh. Appointed to Panora in 1859 he remained two years being admitted to full Conference membership in 1860. Came two years at Magnolia, then appointed to Quincy, where along with a large number of parishioners, he enlisted in the Twenty-Ninth Iowa Infantry, which he served as chaplain. On return to civil 
life his appointments were steadily of increasing importance, until in 1869 he entered upon a four year term as presiding elder of Chariton District, followed by twenty-six years in pastorates verging with waning strength toward the minor grades, yet in which he gave the Conference good service as treasurer. With tastes inclined to surroundings like those immortalized in Goldsmith's "Deserted Village," his superannuated years were passed on a small acreage in Nevinville, his last pastoral field. His passing occurred April 17, 1895.

Scottish by birth, in physiognomy, and slightly in accent, Dugald Thompson, with genuine Scotch love of scholarship, attained college and seminary honors before coming west, and joining Iowa Conference on trial at its first Des Moines session in 1857. During thirty-four years of ministerial life his appointments were diffused over much of the area we are studying, extending from Sidney to Nevada. He was four years presiding elder of Winterset District. His later years were devoted to charges principally contiguous to Des Moines, and on superannuation he retired to a home in Highland Park, where he passed to his reward in 1896.

Eli M. H. Fleming came to Iowa after four years of Indiana pastorates. His relation to Monroe Circuit and East Des Moines Mission have already been appraised. The next year on Newton Circuit made possible the setting off of Greencastle Circuit from that field. Stationed at Indianola in 1859 , besides all the labors of that growing parish, he materially aided in launching the educational enterprise which gives that town its chief distinction. As secretary of the Conference in 1860, he gave large assistance to Bishop Janes in organizing the body to which the rest of his life was devoted. A roster of his appointments would include all the more prominent parishes in Des Moines Conference until waning strength demanded less demanding fields of labor. He was presiding elder three terms, serving in turn Chariton, Council Bluffs and Atlantic Districts. He was once delegate 
to General Conference, and identified almost invariably with every forward looking project of the Church at large, the Conference of which he was member and the congregation he served as pastor. He died July 16, 1898, at Woodbine.

Of Archibald H. Murphy we have little record except the names of his appointments, most of which were minor in importance, yet the fact that several of them were close together, and in one of which he gave a second term after an interval of some years, are indicative of likeability and usefulness in this scholarly, sweet-spirited brother, even though physical disabilities seem to have interferred sadly with his activities, his relation shifting from effective, to supernumerary, to superannuated, through most of the years before his final retirement and location in California, where he passed the last decade of life, dying March 22, 1897.

\section{EARLY IN THE TERRITORY}

John W. Anderson, Virginia born, emigrated to Iowa when it was known only as the Black Hawk Purchase, and began his ministry in 1853, following Samuel Farlow's trail over Page and Taylor Mission; admitted on trial in 1854, he was appointed to Story Mission, then Buena Vista (Harrison county), next Panora; then in succession Newbern, Decatur City, and Greencastle, where in 1865 he asked for the superannuate relation, on account of his wife's impaired health, almost the only instance of retirement due to that cause, on the part of any of the old-time preachers. Barring two years of supply work later on, this terminated his active ministry, although he lived until July 17, 1901, witnessing the skirmish lines he helped man become a mighty phalanx of stations and circuits. A son, Charles W. Anderson, succeeded him in Des Moines Conference ranks, and now a granddaughter, Miss Grace Anderson, carries on the family tradition as accepted supply pastor.

Of Samuel Farlow much has been said, but much remains suitable for this record. He came to Iowa at seven- 
teen years of age, and here he passed fifty-nine years of ministerial service. Converted soundly at sixteen, three years later he entered into a higher state of grace, witnessing throughout life to the genuineness of these experiences both by walk and conversation. At twentyone he gave himself to the gospel ministry. When appointed to Page and Taylor Mission a friend warned him of the necessity of being on his guard against lawlessness on that remote frontier. "Oh! I am well protected; I carry two guns that never miss fire!" he answered, producing from his saddle bags his well worn bible and hymn book, besides which he needed no other armament, for although dangerous characters were not few in that border land between freedom and slavery, the most ungodly could entertain nothing but respect for one who in sincere earnestness labored for their present and eternal welfare. It was the writers good fortune to serve two charges where this good man had spent respectively four and two pastoral terms, and two others in which he had been a distant predecessor, and found his memory green in every case despite lapse of time. His modest store of talents never equalled the demands of any great church, but in a long succession of small ones he provided the material of which the great ones are built. He died Nov. 26,1906 , a workman of whom neither his family nor the Church he loved needed to be ashamed.

Differing widely in type, abilities, early attainments and grade of appointments, but one in modesty of spirit with the foregoing, was the next to find place in our Conference Necrology, Charles Chauncey Mabee. He was of French Huguenot ancestry, the child of Methodist parents who died in his early childhood. He gave four years service as supply pastor and Conference probationer in New York, then joining a brother living in Alabama, he identified himself with the M. E. Church South, and received ordination both as deacon and elder while teaching school, and laboring as local preacher. Returning north, he acted as financial agent for Dickinson College, Carlisle, Penn., for four years, then taught 
school in Oskaloosa, Iowa, until 1859, when he was assigned to supply Winterset charge after the pastor's failure in health. That fall he joined Iowa Conference, and was appointed to Chariton, inaugurating thirty-seven years of continuous service in the more prominent fields of Des Moines Conference. He had four pastorates in Des Moines, four years presiding elder of Des Moines District, with Indianola, Fort Dodge, Council Bluffs, Clarinda, as only the more noted of his other parishes. He passed from earth to heaven Nov. 2, 1907. "A rare man, unusually free from those traits that antagonize men; his experience was deep and rich, his gentleness and devotion unsurpassed. He never murmured about any appointment, but.went in faith and love to do the best he could." So reads a portion of his obituary, penned by one who knew him well.

His passing left but one surviving charter member in Des Moines Conference, Benjamin Shinn, who tarried with us until Sept. 8, 1913, fifty-seven years after he began his ministry as supply pastor on Indianapolis Circuit, under William Simpson, presiding elder. Received in 1857 along with several others of this group, his trial years were passed at Millersburgh, following which, appointment to Corydon in 1859 qualified him as a member of the new Conference, stricken off the next year. Then came seriatim, Mount Ayr, Clarinda, Leon, Garden Grove, Afton, Nevada, Denison, Sidney; 1872-76, presiding elder of Council Bluffs District, with hardships, privations and toils, far exceeding all the honors supposedly attached to the sub-episcopal office. Taking the supernumerary relation he engaged in business for a time; returning to the pastorate, he served series of charges suited to advancing years with their attendant handicaps. Followed fifteen years of retirement and the end. "God endowed Brother Shinn with large mental and spiritual gifts; as a preacher of the word, he was a plain, practical, animated and earnest dispenser of gospel truth. Both in and out of the pulpit his deportment was uniformly that of an ambassador of God. Habitually artless, af- 
Iowa Methodism?" His portrait hangs in our Iowa State fable and dignified in his manners, and strictly conscientious in walk and conversation, he won and retained the affection of his brethren, and the veneration of all who knew him." Blessed must be they who are permitted to read such tributes to the memory of one whom they loved.

\section{Bishop Mitchell's Great Career}

We must include in this category the name of Bennett Mitchell, for, received on trial by Iowa Conference while yet state-wide in extent, he was charter member successively of Western Iowa, Des Moines and North West Iowa Conferences; served more districts than perhaps any other man in the state's history, besides pastorates inferior to none in standing. After four years in eastern Iowa, he went to Afton in 1859 ; to Bedford 1860 and 1861. Then with only seven years experience back of him, in $\mathbf{1 8 6 2}$ he was appointed presiding elder of Council Bluffs District; three years later, skipping the usual pastoral interval between district work, he was changed to the yet more responsible field of Chariton District, where the Burlington railway was pushing its line westward, replacing old centers of population with new stations, calling for statesmanlike judgment in the readjustments of circuit boundaries and parsonage locations.

That term completed he went to Sioux City District, and the large opportunities offered with northwestern Iowa and all the Dakotas in his super parish. He was General Conference delegate in 1868 and 1872, at the last of which sessions North West Iowa Conference was created, in which he served as presiding elder, church builder, college promoter, historian, and frequent representative in the highest councils of the denomination, where his voice and influence were as potent as any of his colleagues, and in one of which he missed by a single vote election to the office of bishop, highest and most responsible post in the Methodist economy. Would you see the patriarchal countenance of him who, more than any 
other one person might justly be termed "Father of all Historical Building in Des Moines, amongst those of our most renowned citizens, our chosen leaders in both war and peace, not one of whom is more worthy of his place in our Hall of Fame, than this trail-blazing, foundationlaying Methodist minister.

And what of the good women, who, through lonely days and nights, kept the home fires burning to cheer and comfort the good men, who, being so much more in the public eye, were so much better known to fame than themselves? The materials are lacking to portray many who shared the toils and triumphs outlined above; not until 1876 did their memoirs begin to appear in Des Moines Conference Journals, and most writers of obituaries so identify the wife with her husband's work as to almost sink her personality in his. We subjoin below some extracts from the obituary of one, who, although not companion of any presented in the preceding pages, so exemplified Solomon's appraisal of "A Good Woman," that her memoir, with suitable modifications may stand as a general characterization of not only the pioneer queens of the parsonage, but a very great proportion of their successors throughout the intervening two generations of church life.

"Mrs. Artemas Brown was a splendid example of the old-fashioned wife and mother. While a large portion of her life was passed in a manner which at the present time would be considered very toilsome, and in the early days of pioneering in the west, had much of hardship in it, she was ever resolutely cheerful, and found her chiefest happiness in some form of useful employment or Christian service. And to her work was not drudgery, especially when it was done for her family or the Church. And it was in the home that her virtues shone with the brightest lustre. There she found not only her highest duties to perform, but counted them her greatest contribution to life and character. While her own faith was strong, and her opinions firm, she looked with greatest charity upon 
those with whom she differed, and with pity upon the erring. Her whole life was beautiful in its simplicity, its charity, its kindness and a pleasurable devotion to duty."

\section{[CONCLUDED]}

\section{AN IOWA NEWSPAPER SCOOP}

Peter Melendy was a delegate to the national convention at Baltimore that nominated Abraham Lincoln for a second term and named Andrew Johnson as his running mate. Mr. Melendy was very close to the Perkinses who then owned the Cedar Falls Gazette, and later the Sioux City Journal. In the Life of Peter Melendy, by Luella M. Wright, this story is told:

Before leaving for the convention, Melendy contrived a plan whereby the Gazette could scoop nearby papers in announcing the name of the successful candidate for vice president. It was decided that Melendy should compose a telegram and sign it with the name of the vice presidential nominee. At the close of the convention Melendy, therefore, made his way to the telegraph booth and, assuming as serious a countenance as possible, pushed before the eyes of the harried telegrapher the following near-death message:

Baltimore, Md. June 8th, 1864. Henry A. Perkins, Cedar

Falls, Ia. Your mother very sick come at once. Johnson.

Because of the implied urgency of imminent death, the agent gave it precedence over political matter, and sent the coded message clicking over the wires. H. A. Perkins immediately completed the printing of handbills and supervised their distribution throughout Cedar Falls and the countryside. The Johnson signature was notice that Andrew Johnson had been nominated on the ticket with Abraham Lincoln. In this way he secured what was probably the first telegraphic scoop in Black Hawk county annals.

\section{AN EARLY IOWA “TRAILER"}

We saw on our streets yesterday a regular cabin on wheels, conveying some family over the prairies. It had sash, doors, glass windows, a stove, and looked quite comfortable.-Iowa City Republican 1868. 
Copyright of Annals of Iowa is the property of State of Iowa, by \& through the State Historical Society of Iowa and its content may not be copied or emailed to multiple sites or posted to a listserv without the copyright holder's express written permission. However, users may print, download, or email articles for individual use. 